\title{
Response of grafting tobacco to low potassium stress
}

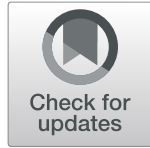

Wei $\mathrm{Hu}^{1,2}$, Qing $\mathrm{Di}^{2}$, Jie Zhang ${ }^{3}$, Jia Liư ${ }^{4}$ and Xiaojun Shi ${ }^{1 *}$

\begin{abstract}
Background: In the previous study, we investigated the alleviation effect of grafting on potassium uptake in roots and tobacco growth inhibition under low potassium stress. However, the effect of grafting on the low potassium stress perception and coping mechanism of tobacco at the whole plant level is not clear now. In order to clearly understand the impact of grafting on potassium deficit responding mechanism in tobacco, a mutual grafting

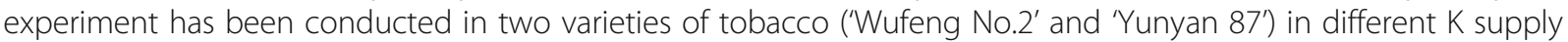

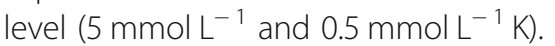

Results: The results show that compared with the self-rooted seedlings, grafting significantly increased the potassium content of the whole plant of Yunyan 87 (97.57 and 189.74\% under normal potassium and low potassium conditions, respectively), and the increase in shoots was greater. The data of whole plant $\mathrm{K}$ content distribution and tobacco hypocotyls net $\mathrm{K}^{+}$flux demonstrates that potassium stress makes plants more inclined to maintain $\mathrm{K}^{+}$in the shoot rather than root. In addition, when $\mathrm{K}$ deficiency occurs, grafting could reduce the time required for downward net $\mathrm{K}^{+}$flux in tobacco hypocotyl to decrease to stable levels. The results of net $\mathrm{K}^{+}$flux in the roots indicated that $\mathrm{K}$ channel proteins and transporters play different roles in two rootstocks in terms of potassium tolerance. Transcription level analysis suggested that the increased circulating efficiency of $\mathrm{K}^{+}$between the shoots and roots in tobacco constitutes one means to low potassium stress adaptation.

Conclusions: Grafting can activate more $\mathrm{K}^{+}$channels in tobacco 'Yunyan $87^{\prime}$ ', this means a more active $\mathrm{K}^{+}$cycle, higher potassium content in shoot and faster response to low potassium stress signals in grafting tobacco. In addition, grafting can also change the $\mathrm{K}^{+}$absorption mode of tobacco root from being dominated by HATS to being jointly responsible by HATS and LATS, greatly improving the ability of $\mathrm{K}^{+}$transmembrane transportation on root surface under low potassium stress. These are undoubtedly the reasons why grafting tobacco performs better in coping with low potassium stress.
\end{abstract}

Keywords: Grafting, Tobacco, Potassium stress, $\mathrm{K}^{+}$channel current, Net $\mathrm{K}^{+}$flux

\section{Background}

As a macronutrient for the growth of flue-cured tobacco (Nicotiana tabacum), potassium (K) is also an important limiting factor for high quality flue-cured tobacco in China. The formation of nucleic acids proteins, carbohydrates and the processes of photosynthesis, enzyme

\footnotetext{
* Correspondence: shixj@swu.edu.cn

${ }^{1}$ College of Resources and Environment, Southwest University, Chongqing 400716, China

Full list of author information is available at the end of the article
}

activation and osmoregulation are all associated with $\mathrm{K}$ $[1,2]$. A common sense in the cigarette industry is that the importance of tobacco leaves $\mathrm{K}$ content in the quality evaluation system cannot be underestimated. Tobacco plants growing under conditions that allow for a sufficiently high accumulation of $\mathrm{K}$ are associated with a product with improved aromatic taste, flammability, and processability of the leaves [3]. But, for most tobacco planting regions in China, the low available $\mathrm{K}$ content in the tobacco planting soil makes $\mathrm{K}$ levels in tobacco

(c) The Author(s). 2020 Open Access This article is licensed under a Creative Commons Attribution 4.0 International License, which permits use, sharing, adaptation, distribution and reproduction in any medium or format, as long as you give appropriate credit to the original author(s) and the source, provide a link to the Creative Commons licence, and indicate if changes were made. The images or other third party material in this article are included in the article's Creative Commons licence, unless indicated otherwise in a credit line to the material. If material is not included in the article's Creative Commons licence and your intended use is not permitted by statutory regulation or exceeds the permitted use, you will need to obtain permission directly from the copyright holder. To view a copy of this licence, visit http://creativecommons.org/licenses/by/4.0/. The Creative Commons Public Domain Dedication waiver (http://creativecommons.org/publicdomain/zero/1.0/) applies to the data made available in this article, unless otherwise stated in a credit line to the data. 
leaves unable to meet the global standards for highquality tobacco. According to a recent soil survey, 63.1\% of tobacco planting soil in China is below the critical available $\mathrm{K}$ content level of $150 \mathrm{mg} / \mathrm{kg}$. Of this soil, $19.6 \%$ is extremely $\mathrm{K}$ deficient, and the average available $\mathrm{K}$ content is only $57.5 \mathrm{mg} / \mathrm{kg}$ for this region. The remaining $43.5 \%$ constitutes K-deficient soil [4]. Improving the uptake and utilization efficiency of $\mathrm{K}$ in tobacco has thus become an important issue in tobacco farming.

$\mathrm{K}$ is highly mobile in plants and can be transported from the root to the shoot. This function plays a significance part in the electrical balance and energy conservation of plants. The $\mathrm{K}$ channel genes SKOR and AKT2 determine the redistribution of $\mathrm{K}^{+}$in plants. The former is abundantly expressed in the pericycle and xylem parenchyma cells in the root system, which mediate the transport of $\mathrm{K}^{+}$to the shoots [5], while the latter is abundantly expressed in the phloem vascular system of the roots and leaves, which dominates the loading and unloading of $\mathrm{K}^{+}$in the phloem [6]. When plants perceive external $\mathrm{K}$ deficit signals, cells produce both short-term and long-term response patterns: for short-term responses, $A K T 1$ expression is up-regulated, and $\mathrm{K}$ levels in the cytoplasm are maintained by releasing $\mathrm{K}^{+}$in the vacuoles. For the long-term response, when the stress period lasts for several days or even weeks, the $\mathrm{K}^{+}$concentration in the cytoplasm is decreased, the metabolic processes of the plant cells are affected, the activity of $\mathrm{H}^{+}$-PPase dependent on $\mathrm{K}^{+}$activation is inhibited, and the pyruvate content is decreased [7]. Apart from this, cell elongation in the root elongation zone of plants requires cell swells produced by $\mathrm{K}^{+}$. If the $\mathrm{K}$ concentration is low, the root morphology of the plant will change. The growth of the main root is inhibited, and the growth of the root hair becomes strong. This adaptation to the environment is determined by the combination of $\mathrm{NH}_{4}{ }^{+}$ and growth hormones [8]. Functional complementation experiments of a mutant confirmed the involvement of ethylene in low-K stress signal transduction as well as its close regulation of root morphology [9]. Studies on the Arabidopsis auxin synthesis gene deletion mutants aux1, axr1, and axr2 indicate that auxin is also a component of the response mechanism of the root morphology to $\mathrm{K}$ stress [10].

Grafting has been widely used for the improvement of crop quality, growth and yield; to alter varieties; to increase environment stress resistance; and to optimize cross-pollination [11-15]. Beyond that, grafting also has a significant impact on improving plant nutrient uptake [16-18]. However, few data in literature as regards the impacts of grafting on the tolerance of tobacco to K starvation stress. In the previous study [19], we investigated the alleviation effect of grafting on potassium uptake in roots and tobacco growth inhibition under low potassium stress. However, the effect of grafting on the low potassium stress perception and coping mechanism of tobacco at the whole plant level is not clear. This article aims at this goal, through the study of the genes related to potassium transport in phloem and xylem, the net $\mathrm{K}^{+}$flux at the hypocotyl, the intensity of the inward current in $\mathrm{K}^{+}$channel, the distribution mode of potassium content in the shoot and root of the tobacco plant to analyzes the adaptation mechanism of different genotypes of tobacco under low potassium stress and the influence of grafting on them.

\section{Results}

\section{$\mathrm{K}$ distribution between the shoots and roots}

$\mathrm{K}^{+}$absorption and distribution were both affected by the grafting treatment (Fig. 1). K stress significantly decreased the whole-plant $\mathrm{K}^{+}$uptake capacity. However, the whole-plant $\mathrm{K}$ content performances of the different graft combinations differed. Under the $+K$ treatments, whole $\mathrm{K}$ content in the treatments using $\mathrm{K}$ efficient genotype tobacco 'Wufeng No.2' (W) as rootstock increased by $97.6 \%$ compared with The common cultivar 'Yunyan 87' (Y). In the $-\mathrm{K}$ treatments, this raised to $137.76 \%$. In addition, differs from the data of the $+\mathrm{K}$ treatments, whole $\mathrm{K}$ content in $\mathrm{W} / \mathrm{Y}$ significant higher than $\mathrm{Y}$ under low $\mathrm{K}$ supply. This demonstrates that $\mathrm{W}$ tobacco as the scion could improve the $\mathrm{K}^{+}$absorption of genotype $\mathrm{Y}$ tobacco under $\mathrm{K}^{+}$deficit. Under the $-\mathrm{K}$ treatments, the average $\mathrm{K}$ content percentage in the shoots accounted for $44.3 \%$ of the total plant, which was $7.3 \%$ higher than that in $+\mathrm{K}$ treatments. Furthermore, the tendency of the $\mathrm{K}$ in the tobacco plants to tilt toward the shoots under $\mathrm{K}$ stress was more pronounced in the $\mathrm{W}$ and $\mathrm{Y} / \mathrm{W}$ grafting combinations.

\section{$\mathrm{K}^{+}$channel inward current in root cells}

The potential difference generated by $\mathrm{K}^{+}$transmembrane transport in the protoplasts of root cells is the current intensity of $\mathrm{K}^{+}$channel, which could reflect the transport capacity of $\mathrm{K}^{+}$mediated by channel proteins. The inward currents in the $\mathrm{K}^{+}$channel could be recorded by patch-clamp to evaluate the effects of different treatments on the $\mathrm{K}^{+}$channel transport function in root cells. As shown in Fig. 2, with the normal potassium supply, the maximum value of the inward current in $\mathrm{K}^{+}$channel of root cells of $\mathrm{W}$ genotype was $-127.83 \mathrm{pA}$, while that in $\mathrm{Y}$ was $82.57 \mathrm{pA}$. With the low potassium stress, the maximum value of the $\mathrm{K}^{+}$channel inward current of root cells in the two genotypes decreased significantly, with a decrease of $52.33 \%$ in $\mathrm{W}$ and $85.15 \%$ in $\mathrm{Y}$. From the analysis of the I-V curve, it can be known that with the normal potassium supply, the current 


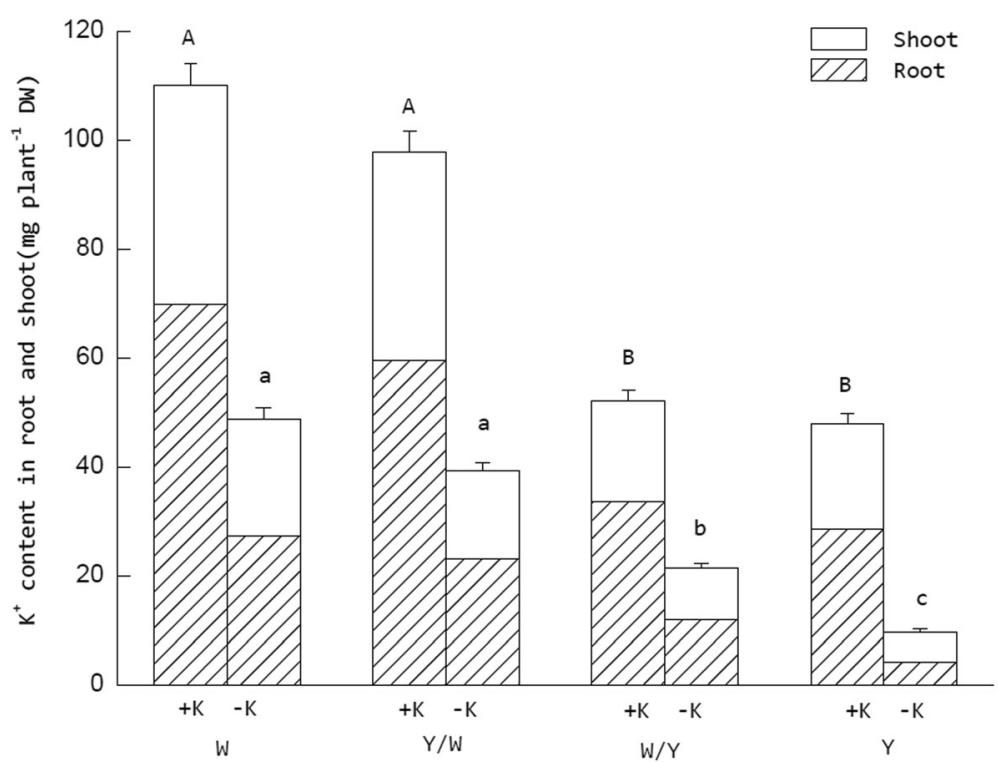

Fig. 1 Effect of grafting combination and $\mathrm{K}^{+}$supply level on $\mathrm{K}^{+}$distribution in tobacco plants. The tobacco graft combinations included the nongrafted tobacco W (Wufeng No.2) and Y (Yunyan 87) and grafted tobacco Y/W (Y grafted onto W) and W/Y (W grafted onto Y). Different uppercase letters denote significant differences $(P<0.05)$ under normal $\mathrm{K}$ levels $\left(5 \mathrm{mmol} \mathrm{L}^{-1}\right)$ in potassium content of whole plant, and lowercase letters indicate significant differences $(P<0.05)$ under starvation $\left(0.5 \mathrm{mmol} \mathrm{L}^{-1}\right)$

density of $\mathrm{W}$ genotype was $81.33 \mathrm{pA} / \mathrm{pF}$ at $-130 \mathrm{mV}$ voltage and that of $\mathrm{Y}$ was $53.44 \mathrm{pA} / \mathrm{pF}$, which was reducing $34.28 \%$. Under the condition of low potassium, the decrease rate reached $78.5 \%$. Moreover, the I-V curve of genotype $\mathrm{Y}$ was always above that of $\mathrm{W}$ regardless of the potassium level. This result first indicates that the transmembrane transport efficiency of
$\mathrm{K}^{+}$channel was weakened under low potassium stress; Secondly, regardless of the potassium level, the $\mathrm{K}^{+}$ channel inward current intensity of genotype $\mathrm{W}$ was always stronger than that of $Y$, which was one of the difference sources in potassium absorption and transport capacity between the two flue-cured tobacco genotypes.
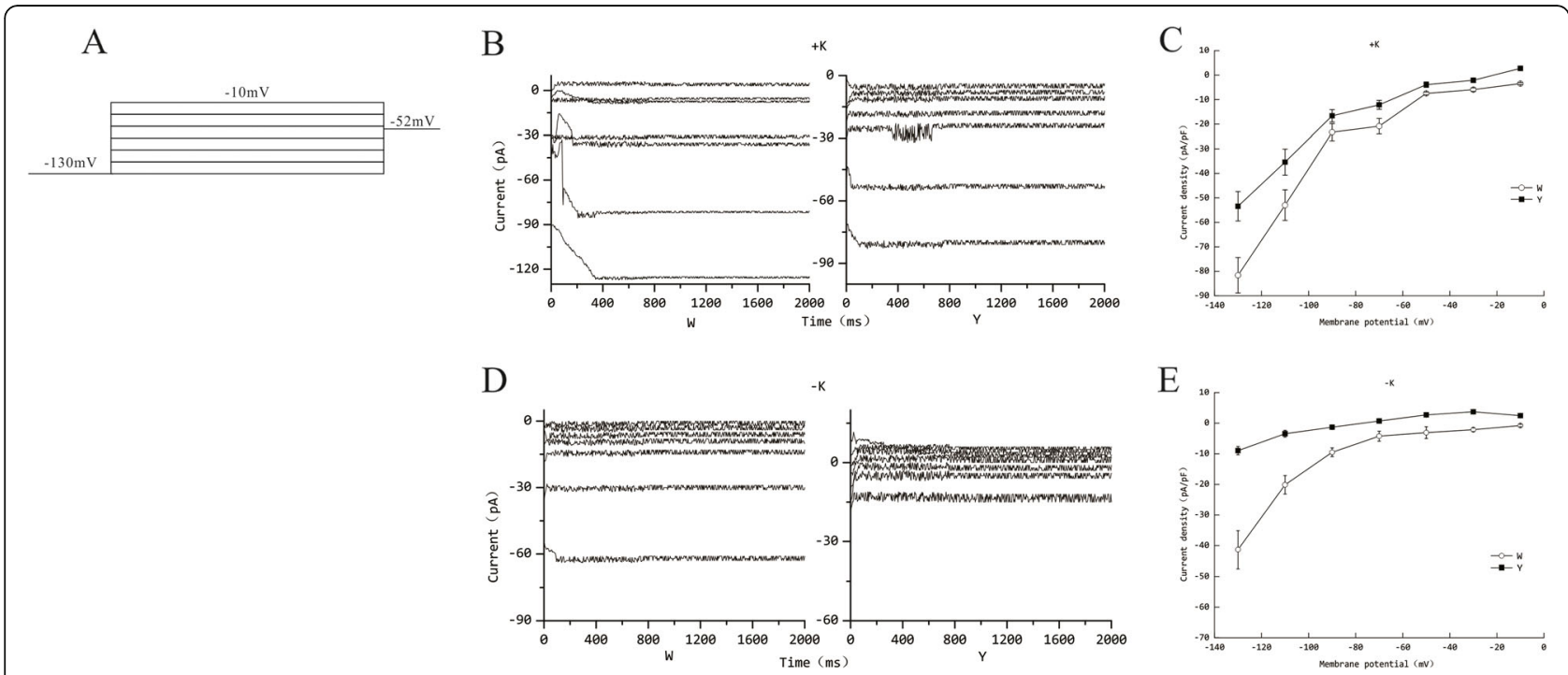

Fig. 2 The inward current of $\mathrm{K}^{+}$channel in flue-cured tobacco root cells under different potassium levels. $\mathbf{a}$. The currents were recorded at the membrane potentials from - 130 to $-10 \mathrm{mV}$ (in $20 \mathrm{mV}$ steps) with the holding potential of $-52 \mathrm{mV}$; $\mathbf{b}$. The inward current of $\mathrm{K}^{+}$channel with normal potassium supply; c. Current amplitude reflected by I-V curve with normal potassium supply; $\mathbf{d}$. The inward current of $\mathrm{K}^{+}$channel with low potassium stress; e. Current amplitude reflected by I-V curve with low potassium stress 
The response of net $\mathrm{K}^{+}$flux in tobacco hypocotyls under $\mathrm{K}$ stress

The experimental data show that when the $\mathrm{K}$ concentration has changed in the external environment, the contrast of the upward and downward net $\mathrm{K}^{+}$flux at the transverse sections of the tobacco hypocotyls was also altered. In the $+\mathrm{K}$ treatments, the mean net $\mathrm{K}^{+}$shoot-toroot flux in the transverse section of the hypocotyls was $1782.72 \mathrm{pmol} \mathrm{cm}^{-2} \mathrm{~s}^{-1}$, which was 1.59 times higher than that of the root to shoot (Fig. 3a). Additionally, there was no significant difference in individual upward or downward net $\mathrm{K}^{+}$flux between each grafting combination (Fig. 3b). In order to clarify the relative direction of $\mathrm{K}^{+}$movement in long-distance transportation under different $\mathrm{K}$ levels, the value obtained by subtracting the downward net $\mathrm{K}^{+}$flux from upward net $\mathrm{K}^{+}$flux has been defined as the relative $\mathrm{K}^{+}$flux intensity. The relative $\mathrm{K}^{+}$ flux intensity in each treatment was negative during the entire measurement period under the $+\mathrm{K}$ treatments, which suggests that $\mathrm{K}^{+}$in the tobacco plants tends to move from the shoot to the root when the $\mathrm{K}$ supply is sufficient (Fig. 3c). In the $-\mathrm{K}$ treatments, the $\mathrm{K}^{+}$flux from the root to shoot of each grafting combination was stable throughout the entire measurement period, and the difference between each grafting combination was not significant. However, the rate of $\mathrm{K}^{+}$flux from the shoot to root in the treatments using $\mathrm{W}$ as the rootstock decreased rapidly after the start of the test and gradually stabilized after $5 \mathrm{~min}$. As for the treatments using $\mathrm{Y}$ as the rootstock, the rate of $\mathrm{K}^{+}$flux was stable after $16 \mathrm{~min}$ of decline (Fig. 3d). The mean net $\mathrm{K}^{+}$efflux of the shoot to root in the transverse section of the hypocotyls was $373.45 \mathrm{pmol} \mathrm{cm}^{-2} \mathrm{~s}^{-1}$, which was $52.3 \%$ of that of the root to shoot. At the same time, the net $\mathrm{K}^{+}$flux from the shoot to root in the treatments using $\mathrm{W}$ as the rootstock was significantly lower than the treatments using $\mathrm{Y}$ as the rootstock (Fig. 3e). Contrary to the $+\mathrm{K}$ treatments, the relative $\mathrm{K}^{+}$flux intensity in each treatment was positive during the entire measurement period under the $-\mathrm{K}$ treatments, which indicates that $\mathrm{K}^{+}$in the tobacco plants tended to move from the root to the shoot when the K supply was insufficient (Fig. 3f).

\section{The effects of $\mathrm{K}$ deficit on the acquisition of $\mathrm{K}^{+}$by the tobacco roots}

According to the data analysis of $\mathrm{K}^{+}$flux in the tobacco roots, significant differences in the strategies of the tobacco varieties $\mathrm{W}$ and $\mathrm{Y}$ in tolerating low $\mathrm{K}$ stress in the

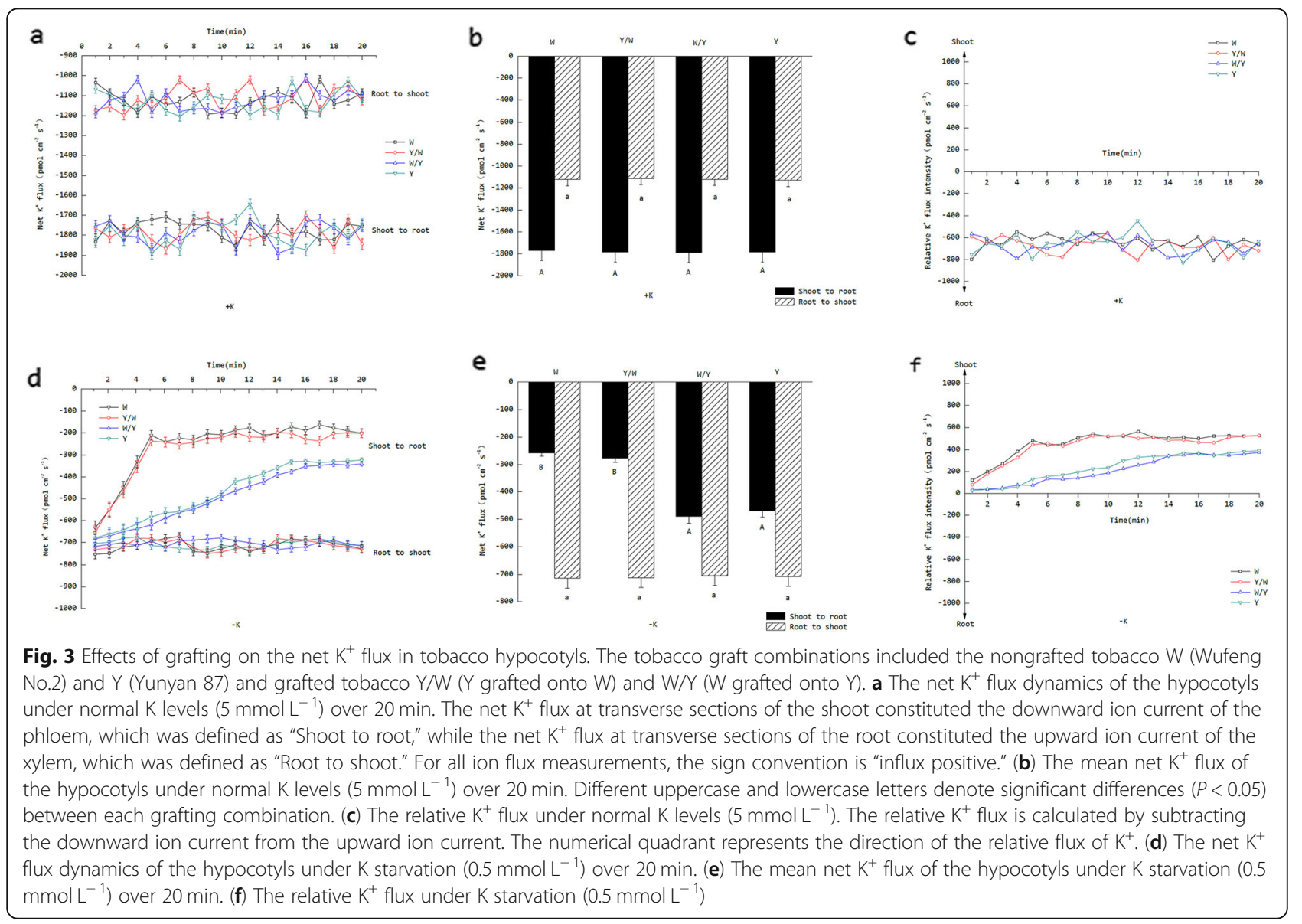


environment were observed. In the $+\mathrm{K}$ treatments, the mean net $\mathrm{K}^{+}$influx of $\mathrm{W}$ in the root meristem was $549.05 \mathrm{pmol} \mathrm{cm}^{-2} \mathrm{~s}^{-1}$, which was 1.13 -times higher than that of Y. When the two tobacco rootstocks were pretreated with cesium chloride (a potassium ion channel inhibitor), the net $\mathrm{K}^{+}$influx in both treatments was significantly lower than the rootstocks without the inhibitor. In addition to this, the decline of mean net $\mathrm{K}^{+}$influx in $\mathrm{W}$ roots was $52.6 \%$, but only $37.5 \%$ in Y. However, when the pretreatment agent was replaced with orthovanadate (a plasma membrane $\mathrm{H}^{+}$-ATPase inhibitor), there was no significant effect on the net $\mathrm{K}^{+}$influx in the roots of the two treatments compared with the original rootstocks (Fig. 3a and b). In the $-\mathrm{K}$ treatments, the mean net $\mathrm{K}^{+}$influx of $\mathrm{W}$ in the root meristem was still significantly higher than Y. However, when the specific inhibitors were involved in the trial, the situation differed from that of the $+\mathrm{K}$ treatments. Cesium chloride significantly reduced the $\mathrm{K}^{+}$flux in the $\mathrm{W}$ root meristem, whereas there was no significant effect on Y (Fig. 4c and d). However, orthovanadate had a significant effect on net $\mathrm{K}^{+}$flux in both the tobacco rootstocks, with $\mathrm{Y}$ exhibiting a greater decline (the decrease was $15.4 \%$ more than W).

\section{Effects of grafting on the expression of genes related to $\mathrm{K}$ absorption and transport}

The qRT-PCR results indicated that the transcription level of SKOR and $A K T 2$ in the tobacco plants had been significantly increased by $\mathrm{K}$ deficit. As reveal in Fig. 5, for the different graft combinations, the transcription levels in the groups with $\mathrm{W}$ as the rootstock were significantly higher than those groups with $\mathrm{Y}$ as the rootstock under normal $\mathrm{K}$ supply levels. A similar situation was observed under $\mathrm{K}$ starvation. However, the expression level of $S K O R$ and $A K T 2$ in the $\mathrm{W} / \mathrm{Y}$ treatments was significantly higher than $\mathrm{Y}$ when $\mathrm{K}$ deficiency and it was not significantly lower than the $\mathrm{W}$ and $\mathrm{Y} / \mathrm{W}$ grafting treatments.

\section{Discussion}

\section{$\mathrm{K}$ starvation changes the distribution trend of $\mathrm{K}^{+}$in} tobacco

Different genotypes in the same crop variety sometimes differ greatly in nutrient uptake and transformation. Grafting can effectively utilize this feature to combine nutrient-efficient rootstocks with target scions to improve crop quality and yield [20-23]. In tobacco, the uptake of multiple nutrients can be influence by grafting $[24,25]$. In our study, the W tobacco was not only superior to the $\mathrm{Y}$ in terms of whole $\mathrm{K}$ content, but its performance was also enhanced when $\mathrm{W}$ was used as the rootstock. Regardless of whether there was normal $\mathrm{K}$ supply or $\mathrm{K}$ starvation, the $\mathrm{K}$ content of the plants with the W genotype tobacco rootstock was significantly higher than the plants with the Y genotype. Combined with our previous research [19], grafting not only improved tobacco growth, but also increased the wholeplant $\mathrm{K}$ content of the $\mathrm{Y}$ genotype tobacco compared with the nongrafted original variety. Another interesting observation in the experiment was that the distribution of $\mathrm{K}^{+}$in the tobacco plant changed under $\mathrm{K}$ starvation. Regardless of the $\mathrm{K}$ supply level, the $\mathrm{K}$ content in the roots is typically the highest in the entire plant. However, the tobacco plants were more willing to retain $\mathrm{K}^{+}$ in the shoots than transport it to the roots under $\mathrm{K}$ deficient conditions, which constitutes one of the mechanisms that tobacco plants use to tolerate $\mathrm{K}$ stress. Furthermore, this tendency was more pronounced in the $\mathrm{W}$ and Y/W grafting combinations. When the demand for nutrients in the plant shoots increases, the nutrient concentration through the phloem to the root system decreases, and as a feedback signal, the absorption rate of the ions by the roots is promoted. Similarly, when the demand for nutrients decreases in the shoots, the concentration of nutrients circulating in the phloem increases and inhibits the absorption of the corresponding ions by the roots $[26,27]$.

\section{The difference between two genotype flue-cured tobacco} of $\mathrm{K}^{+}$channel current in root cells

The Shaker family of the $\mathrm{K}^{+}$channel is currently the most studied channel protein family. It is generally believed that S4 in its six transmembrane domains (S1-S6) is the transmembrane voltage signal receptor [5], which can stimulate the opening of the channel. While the ring structure between S5 and S6 is responsible for the transmembrane crossing of ions due to its high degree of conservation. The Shaker family can be divided into three types: inward rectifying, outward rectifying and weak inward rectifying, depending on voltage dependence and $\mathrm{K}^{+}$transportation direction. The first one is involved in this experiment [28]. The driving force of $\mathrm{K}^{+}$, which is transferred in the form of passive diffusion in the $\mathrm{K}^{+}$channel, is generated by the potential difference between the membrane and the proton pump out of the membrane. Changes in the external environment, especially abiotic stress factors, can cause stress responses in plants. This not only increases the level of calmodulin, but also accelerates the metabolism of polyamines and reactive oxygen species (ROS), while inhibiting the inward current of $\mathrm{K}^{+}$channels [29]. The experimental data show that low potassium stress would decrease the inward current density of $\mathrm{K}^{+}$channel, but the decline of different genotypes of flue-cured tobacco was not consistent. The inward current of $\mathrm{K}^{+}$channel of $\mathrm{Y}$ genotype flue-cured tobacco is more affected in the face of low potassium stress. However, the inward current density of 


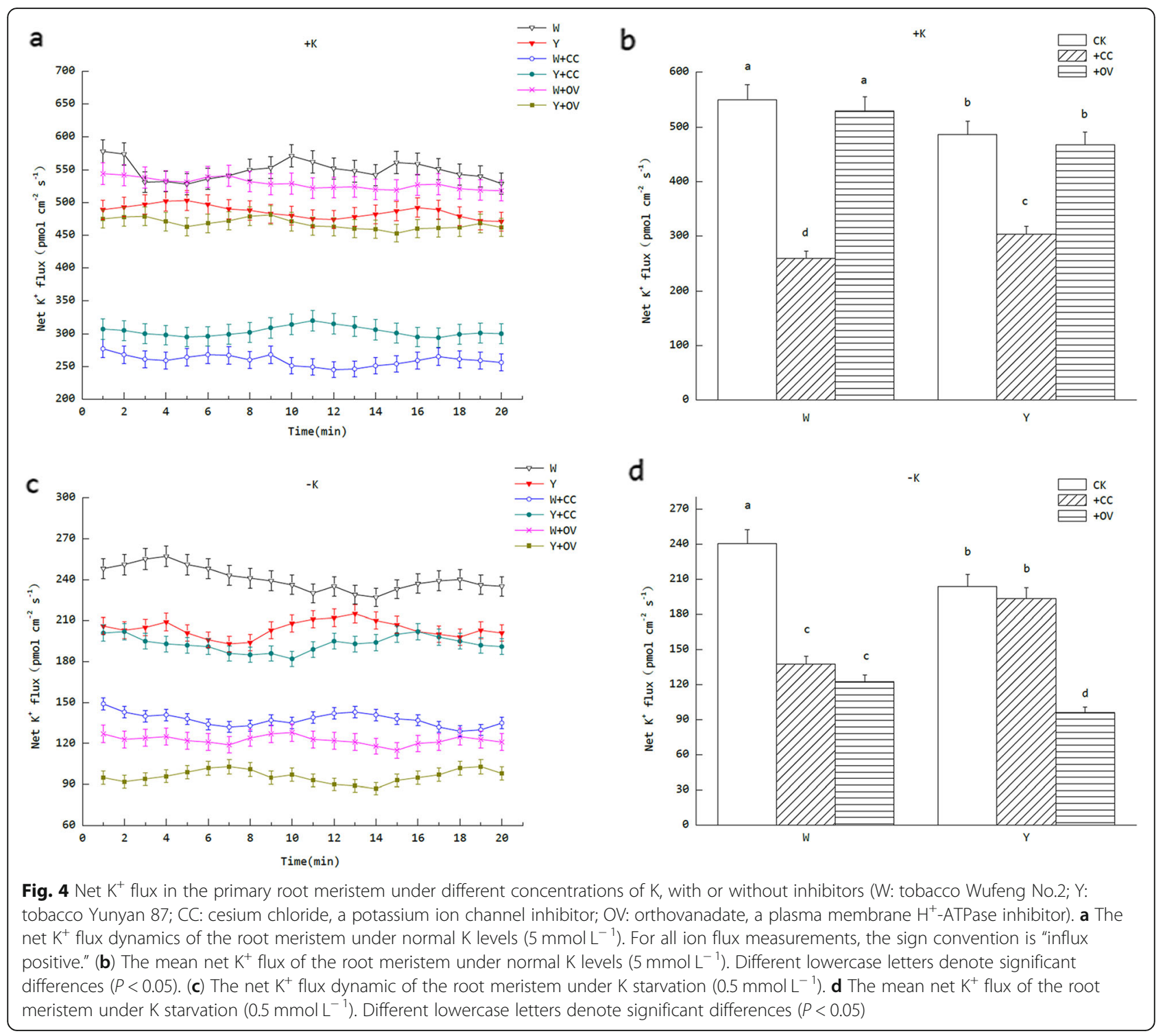

$\mathrm{K}^{+}$channel in W genotype flue-cured tobacco roots was higher than that in $\mathrm{Y}$ regardless of potassium levels. NKT1 is an inwardly rectifying $\mathrm{K}^{+}$channel gene that mediates $\mathrm{K}^{+}$uptake in Shaker-like family expressed in tobacco cells [30]. In our previous studies, it was found that low potassium levels can induce down-regulation expression of this gene [19]. This corresponds to the results of this experiment. By reducing unnecessary consumption, activating more efficient potassium transport pathways (such as potassium transport proteins) may be one of the strategies of potassium efficient flue-cured tobacco to deal with potassium deficit.

\section{Net $\mathrm{K}^{+}$flux in the transverse section of the hypocotyls and root meristem}

$\mathrm{K}^{+}$from the root surface is transversely transported to parenchyma cells and transported from the root to shoot through xylem loading [31], while the phloem circulates $\mathrm{K}^{+}$back to the roots. $\mathrm{K}^{+}$transport in phloem and xylem is adjusted by the $\mathrm{K}$ concentration in each tissue of plant [32]. The experimental data show that the net $\mathrm{K}^{+}$flux transported through the phloem to the root was higher than the net $\mathrm{K}^{+}$flux transported to the shoot by the xylem under $+\mathrm{K}$ treatments. In the case of the $-\mathrm{K}$ treatments, the situation was reversed. The net $\mathrm{K}^{+}$flux of the "root to shoot" was higher than the "shoot to root." This phenomenon confirms the above conclusions regarding the distribution pattern of $\mathrm{K}^{+}$under different $\mathrm{K}$ levels. Under $\mathrm{K}$ deficit, the time required for the downward net $\mathrm{K}^{+}$flux to decrease to a stable state was the same when the rootstocks were the same, and the scions were different. But when the rootstocks differed and the scions were the same, the time required for downward net $\mathrm{K}^{+}$ flux to decrease to stable levels was inconsistent (the 


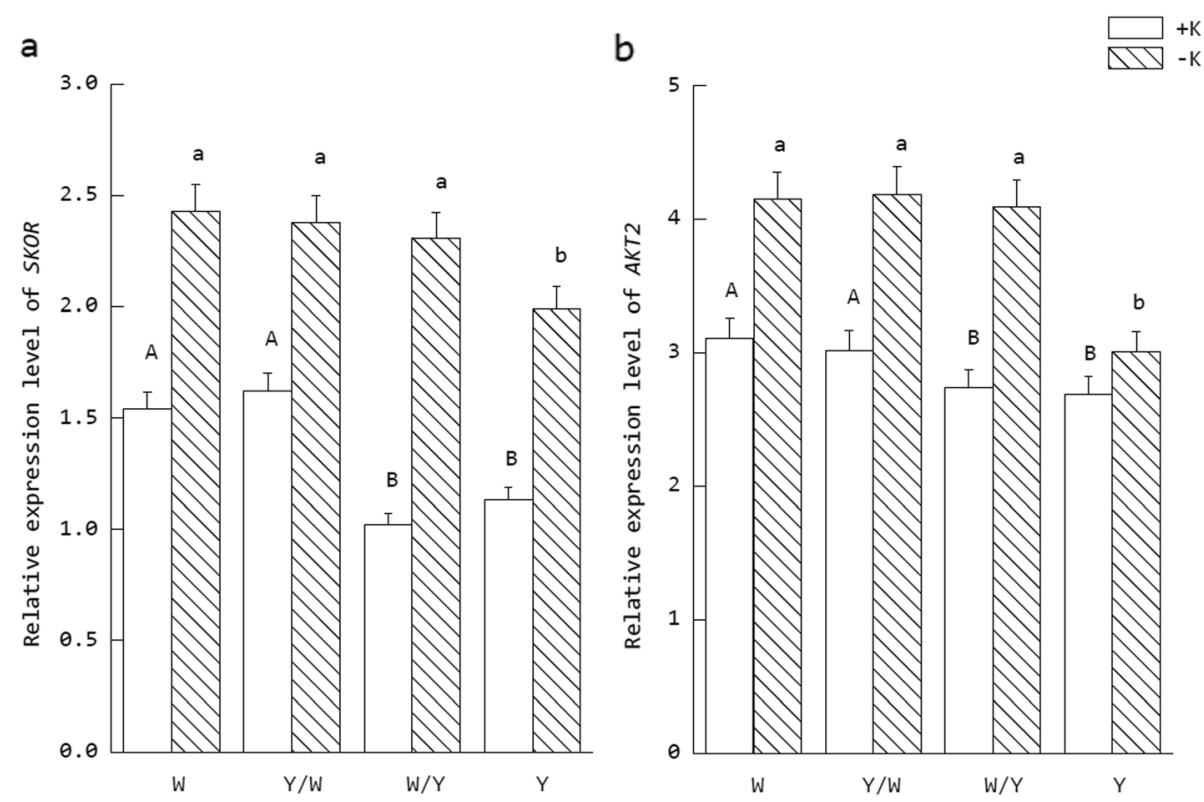

Fig. 5 Relative expression levels of genes (a. SKOR, b. AKT2) related to $K$ absorption and transport in tobacco with two $K$ supply conditions. The tobacco graft combinations included the nongrafted tobacco W (Wufeng No.2) and Y (Yunyan 87) and grafted tobacco Y W (Y grafted onto W) and W/Y (W grafted onto Y). Different uppercase letters denote significant differences $(P<0.05)$ under normal $\mathrm{K}$ levels $\left(5 \mathrm{mmol}^{-1}\right)$, and lowercase letters indicate significant differences $(P<0.05)$ under $\mathrm{K}$ starvation $\left(0.5 \mathrm{mmol} \mathrm{L}^{-1}\right)$

treatments using $\mathrm{W}$ as a rootstock stabilized at $5 \mathrm{~min}$, whereas those using $\mathrm{Y}$ required $16 \mathrm{~min}$ ). This indicates that the sensory mechanism of the $K$ concentration change of the tobacco plant in the external environment is dominated by the rootstocks rather than the scion. This sensory mechanism is mainly derived from the changes in potential on the cell membrane, which is unusually sensitive and is typically observed within several minutes of a decrease in ambient K levels [33, 34]. Studies have shown that there are two major receptors that produce the above potential changes, including the $\mathrm{K}^{+}$channel gene of the Shaker family (mediated by the $A K T 1$ ) and $\mathrm{H}^{+}$-PPase [7]. In addition, the time required for downward net $\mathrm{K}^{+}$flux to decrease to stable levels in treatments using $\mathrm{W}$ as the rootstock was less than that in those using Y. This demonstrates that W-genotype tobacco can alter the distribution pattern of $\mathrm{K}$ in plants more rapidly in the presence of $\mathrm{K}$ stress and can maintain normal $\mathrm{K}$ levels in the shoot by reducing $\mathrm{K}$ circulation in the roots. The ability of the $\mathrm{W}$ genotype tobacco to rapidly respond to $\mathrm{K}$ stress was transmitted to the $\mathrm{Y}$ tobacco through grafting, thus allowing it to respond better to $\mathrm{K}$ deficiency.

High-affinity transport system (HATS) and low-affinity transport system (LATS) are the two way for plants absorption of $\mathrm{K}^{+}$from interface of root and soil [35]. It is evident from the experimental data that the absorption rate of $\mathrm{K}^{+}$in the root meristem of the $\mathrm{W}$ genotype tobacco was significantly higher than that of $\mathrm{Y}$ in the absence of inhibitors. Experiments conducted with specific inhibitors indicate that the dominant $\mathrm{K}^{+}$absorption pattern of the two tobacco rootstocks under normal $\mathrm{K}$ supply levels was a LATS that depended on $\mathrm{K}$ ion channels. The $\mathrm{K}^{+}$absorption method of the W rootstock was operated by LATS and HATS concurrently when K deficit. The HATS transportation volume was larger but the difference with LATS was not significant, which indicates that the status of both $\mathrm{K}^{+}$absorption systems was equally important under $\mathrm{K}$ stress. In addition, the $\mathrm{K}^{+} \mathrm{ab}-$ sorption mode in the root meristem of the $\mathrm{Y}$ rootstock under K deficiency was mainly HATS, whereas LATS was inhibited. The change in membrane potential can be used as a plant response signal to $\mathrm{K}$ deficiency. When the concentration of exogenous $\mathrm{K}^{+}$was low, the plasma membrane was hyperpolarized to activate the $\mathrm{K}$ channel. Conversely, when the concentration of exogenous $\mathrm{K}^{+}$ was high, the plasma membrane was depolarized. The results of this study indicate that $\mathrm{K}$ channel proteins and transporters in W genotypes play the same important role in coping with $\mathrm{K}$ stress, while only the transporters play a leading role in $\mathrm{Y}$. This is one of the reasons for the difference in $\mathrm{K}^{+}$absorption between two tobacco varieties. Similar findings were also found in salttolerant pumpkin rootstocks [36].

\section{Analysis of gene expression related to the $\mathrm{K}$ transport pathway}

The $\mathrm{K}^{+}$channel family [5], high affinity transporter family [37], co-transporter family [38], reverse transporter 
family, and proton pump genes for energy supply [39] were involved in regulated the process of uptake and transport of $\mathrm{K}$ in tobacco. In the $\mathrm{K}^{+}$channel gene family, $S K O R$ is responsible for the outward flow of $\mathrm{K}^{+}$from xylem, and $A K T 2$ is involved in the loading and unloading of $\mathrm{K}^{+}$in phloem. The former is responsible for the outward rectifying transport of $\mathrm{K}^{+}$, while the latter is responsible for the weak inward rectifying transport [30]. Studies have shown that $A K T 2$ deletion mutation will cause a decrease in the cell membrane potential of phloem cells and affect the concentration of sucrose in the tissue [40]. In terms of transcriptional regulation, $A K T 2$ was not only affected by photophosphorylation, but also induced by nutrient stress. The lack of potassium could lead to the up-regulated expression of $A K T 2$ in wheat root cells and the activation of $\mathrm{K}^{+}$channel. The effect of low potassium level on SKOR and AKT2 was opposite in Arabidopsis [41, 42]. In this experiment, the transcriptional expression was affected by both potassium levels and grafting. The up-regulated expression of $S K O R$ and $A K T 2$ in low $\mathrm{K}$ stress suggests tobacco could improve the transport efficiency of $\mathrm{K}^{+}$by activating more $\mathrm{K}^{+}$channels in shoot to cope with low potassium stress. Notably, the behavior of the W/Y grafting combination under the - $\mathrm{k}$ treatment indicates that this regulation can be transmitted between the root stock and scion by the signal substance.

\section{Conclusion}

Grafting with potassium efficient genotype tobacco "Wufeng No.2" as rootstock can activate more $\mathrm{K}^{+}$channels in the shoot of "Yunyan 87". This means a more active $\mathrm{K}^{+}$cycle, higher potassium content in shoot and faster response to low potassium stress signals in grafting tobacco. In addition, grafting can also change the $\mathrm{K}^{+}$ absorption mode of tobacco root from being dominated by HATS to being jointly responsible by HATS and LATS, greatly improving the ability of $\mathrm{K}^{+}$transmembrane transportation on root surface under low potassium stress. These are undoubtedly the reasons why grafting tobacco performs better in coping with low potassium stress. However, these advantages of grafted tobacco are based on the rapid response of low potassium stress signals. Therefore, to provide insight into the signaling pathway of grafted tobacco in response to low potassium stress, the co-expression analysis of differentially expressed genes and differentially accumulated metabolites in grafted tobacco will be our next work need to do.

\section{Methods}

\section{Plant materials and treatments}

The experiments were conducted in the greenhouse of the Chongqing Academy of Agricultural Sciences,
Chongqing, China $\left(29^{\circ} 36^{\prime} \mathrm{N}, 106^{\circ} 29^{\prime} \mathrm{E}\right)$. The common cultivar 'Yunyan 87' ( $N$. tabacum, Yunnan Tobacco Research Institute, China) and K-efficient genotype tobacco 'Wufeng No.2' (Nicotiana tabacum, Yichang Tobacco Company of Hubei Province, China) were used in the present research. In order to ensure the success rate of grafting, the seeds of rootstock should be planted 7 days before the scion. The 'split grafting' was selected as the grafting method when six to eight true leaves had appeared on the seedlings of the rootstock. When the new leaves had grew by grafted plants, transplanted the plants into hydroponic box, with 12 seedlings planted per container. The nutrient solution for hydroponics was formulated as previous study [19]. Air pumps were adopted to supply oxygen to each container through a hose for oxygen supply to the tobacco seedlings during experiment. The plants were grown at $22.5^{\circ} \mathrm{C}$ under a 16-h light/8-h dark cycle using fluorescent lamps with an average photosynthetic photon flux density (PPFD) of $300 \mu \mathrm{mol} \mathrm{m}^{-2} \mathrm{~s}^{-1}$ in the greenhouse. The relative humidity ranged from 60 to $95 \%$.

Two K levels were used for the experiments: $+K$, sufficient supply $\left(5 \mathrm{mmol} \mathrm{L}^{-1}\right)$ and $-\mathrm{K}$, deficit $(0.5 \mathrm{mmol}$ $\mathrm{L}^{-1}$ ), using $\mathrm{K}_{2} \mathrm{SO}_{4}$ as the substance source to adjust different $\mathrm{K}$ levels. Besides that, four graft treaments [Wufeng No.2 (W), W/Y (W grafted onto Y), Yunyan 87 $(\mathrm{Y})$, and $\mathrm{Y} / \mathrm{W}$ (Y grafted onto $\mathrm{W})$ ] were used in experiment. Eight treatments were replicated 6 times with 12 plants in each replicate. The solutions were replaced every $4 \mathrm{~d}$.

\section{$\mathrm{K}$ content determination in the tobacco}

The tobacco plants were cut into two sections at the hypocotyl below the cotyledon. The stem above the cotyledon was defined as the "Shoot," while the stem below the cotyledon was defined as the "Root." A flame atomic absorption spectrometer was adopted for determining $\mathrm{K}$ content in the dried samples (Varian AA-220FS, Thermo Fisher Scientific, USA) as previously described [43].

\section{Root cell $\mathrm{K}^{+}$channel inward current measurement}

Fifteen days after transplanting, the fibrous roots of $\mathrm{W}$ and $\mathrm{Y}$ genotypes tobacco were collected and washed with deionized water, after then cut them into $5 \mathrm{~mm}$ segments. The treated sample was transferred to $1 \mathrm{ml}$ of the enzymatic hydrolysate ( $1 \%$ cellulase, $0.15 \%$ pectinase, $0.8 \mathrm{~mol} \mathrm{~L}-1$ mannitol, cell wash solution, $\mathrm{pH} 5.5-6.0$ ), shaken for $2 \mathrm{~h}, 70 \mathrm{rpm}$, temperature $28^{\circ} \mathrm{C}$. The enzyme hydrolysates were then filtered with a 200-mesh filter and rinsed twice with cell washing solution under dark conditions. The filtrate was collected, centrifuged for 5 min at $100 \mathrm{rpm}$, removed the supernatant and repeated twice. The sediment was the protoplasm sample. 
Select a suitable hard thin glass tube, and use a two-step method to draw the microelectrode on the drawing instrument (Narishige Japan) and polish it. The inner diameter of the tip is about $0.5-1 \mu \mathrm{m}$, and the intracellular fluid is injected into it [100mmo1 $\mathrm{L}^{-1}$ potassium glutamate, $2 \mathrm{mmo} 1 \mathrm{~L}^{-1}$ magnesium chloride, $0.1 \mathrm{mmo} 1 \mathrm{~L}^{-1}$ calcium chloride, $10 \mathrm{mmo} 1$ $\mathrm{L}^{-1}$ 4-hydroxyethylpiperazine ethane sulfonic acid, 1.1 mmo1 $\mathrm{L}^{-1}$ ethylene glycol double (2-aminoethyl ether) tetraacetic acid, $2 \mathrm{mmo} \mathrm{L}^{-1}$ adenosine triphosphate, $\mathrm{pH}$ 7.2. Mannitol adjusts the osmolality to

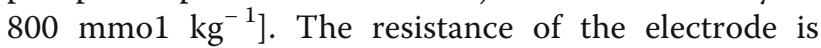
5-8 M $\Omega$. Protoplasts were transferred to a sample pool containing $2 \mathrm{ml}$ cell extracellular fluid (1 $\mathrm{mmo1}$ $\mathrm{L}^{-1}$ calcium chloride, $10 \mathrm{mmo} 1 \mathrm{~L}^{-1}$ potassium glutamate, $5 \mathrm{mmo} 1 \mathrm{~L}^{-1}$ 2-morpholine ethanesulfonic acid, $4 \mathrm{mmo1} \mathrm{\textrm {L } ^ { - 1 }}$ magnesium chloride, pH 6.0. Mannitol adjusts the osmolality to $900 \mathrm{mmol} \mathrm{kg}^{-1}$ ). After forming a high-resistance seal (resistance 1-5 G $\Omega$ ) between the tip of the glass microelectrode and the plasma membrane, begin to apply a negative pressure to the inner cavity of the electrode. During stimulation, the voltage was depolarized from $-130 \mathrm{mV}$ to $10 \mathrm{mV}$, each stage was $20 \mathrm{mV}$, the duration was $2 \mathrm{~s}$ and the frequency was $0.2 \mathrm{~Hz}$. Current signal and membrane capacitance were recorded by Axopatch200B patch clamp amplifier, data acquisition card and Pclamp 6.0 software. The acquisition process was constant at room temperature $\left(25 \pm 1^{\circ} \mathrm{C}\right)$. The channel current density was used to measure the whole cell current intensity $(\mathrm{pA} / \mathrm{pF}$, the ratio of current to cell capacitance) of each treatment, and the current amplitude was analyzed by I-V curve.

\section{Measurement of $\mathrm{K}^{+}$fluxes in transverse sections of the tobacco hypocotyls}

Six plants of each grafting combination in the $+\mathrm{K}$ treatment were chosen to measure net $\mathrm{K}^{+}$-flux with noninvasive micro-test technology (NMT system BIO-IM; Younger Corp., Amherst, MA, USA), ASET 2.0 (Sciencewares, Falmouth, MA, USA) and iFluxes 1.0 (YoungerUSA, LLC, Amherst, MA, USA) software [44, 45], as described previously [46]. Net $\mathrm{K}^{+}$flux was calculated by Fick's law of diffusion [47].

Half of the plants were treated with $0.5 \mathrm{mmol} \mathrm{L}^{-1}$ $\mathrm{K}_{2} \mathrm{SO}_{4}$ for $2 \mathrm{~h}$ before measurement to observe the short- term reaction of each grafting combination under $\mathrm{K}$ stress. The tobacco plants were cut into two sections at the hypocotyl below the cotyledon and then fixed in measuring solution with belts. The transverse section of the hypocotyl was immediately incubated in the measuring solution $\left[0.1 \mathrm{mmol} \mathrm{L}^{-1} \mathrm{CaCl}_{2}\right.$ and $0.3 \mathrm{mmol} \mathrm{L}^{-1} 2$ ethanesulfonic acid (MES), $\mathrm{pH} 6$ ] to equilibrate for 30 min. The equilibrated samples were then transferred to the measuring chamber filled with the solution containing either $0.5 \mathrm{mmol} \mathrm{L}^{-1} \mathrm{~K}^{+}$or $5 \mathrm{mmol} \mathrm{L}^{-1} \mathrm{~K}^{+}$. The electrode was fixed at the center of the transverse section. Net $\mathrm{K}^{+}$fluxes were measured under the experimental conditions for $20 \mathrm{~min}$ to decrease variability due to fluctuations. Each plant was measured once.

\section{Measurement of $\mathrm{K}^{+}$fluxes in the root meristem}

This test only involves the absorption of nutrients by the roots. Thus, only nongrafted tobacco W (Wufeng No.2) and Y (Yunyan 87) were adopted in this trial. The measuring site was the root meristem. In order to elucidate the possible effects of $\mathrm{K}^{+}$channel and plasma membrane $\mathrm{H}^{+}$-ATPase compounds on $\mathrm{K}^{+}$uptake, the net $\mathrm{K}^{+}$fluxes at the root meristem were monitored after the application of orthovanadate, which is a specific inhibitor of PM $\mathrm{H}^{+}$-ATPases [48], and cesium chloride, which is a $\mathrm{K}$ channel blocker. The rest of the measurement methods were consistent with the measurement of $\mathrm{K}^{+}$fluxes in transverse sections of the tobacco hypocotyls.

Total RNA extraction and quantitative real-time (qRT) PCR Total RNA was extracted from stems of ungrafted tobacco and grafted tobacco (SKOR and AKT2) with TRIzol reagent (Invitrogen, ThermoFisher, USA) according to the manufacturer's instructions. $1 \mu \mathrm{g}$ of total RNA in a $20-\mu \mathrm{L}$ reaction system was used to synthesis firststrand cDNA in combination with oligo (dT)-18 as a primer and M-MuLV reverse transcriptase (TaRaKa, Japan). qRT-PCR (ABI 7900HT, Applied Biosystems, USA) was performed by a LightCycler480 SYBR Green I Master kit according to the protocols. Each sample analysis was repeated at least three times. The design of gene-specific primers was made by Primer premier5.0 software and all primers were summarized in Table 1. Each primer presented high specificity by the melting curve analysis. The PCR products were quantified by the $2^{-\Delta \Delta C t}$ method [49].

Table 1 Primers used in the qRT-PCR analysis

\begin{tabular}{llll}
\hline Gene & Accession Number & Forward primer (5'-3') & Reverse primer (5'-3') \\
\hline SKOR & NM_001326274 & TCAGCCTTACACGGTTAGAGTTG & CACCGTAGAAAGCCGCACT \\
AKT2 & NM_001325653 & ACAAGACAATGCCACAATGCTC & AGGAGGAACAACATCGGTGT \\
Actin $^{\mathrm{a}}$ & AB158612 & AACAGTTTGGTTGGAGTTCTGG & CATGAAGATTAAAGGCGGAGTG \\
\hline
\end{tabular}

${ }^{\mathrm{a}}$ Reference gene (Act) for qRT-PCR analysis 


\section{Statistical analysis}

All data in research are presented as the means of six replicates \pm S.D. A two-factorial ANOVA was performed to determine the impacts of grafting on tobacco by SAS Version 9.3 (Statistical Analysis System Institute Inc., Cary, NC, USA). The significance differences between treatments was compared by Duncan's multiple range test $(P<0.05)$.

\section{Abbreviations}

AKT2: Nicotiana tabacum potassium channel AKT2/3-like; SKOR: Nicotiana tabacum Stelar $\mathrm{K}^{+}$outward rectifier; qPCR: quantitative real-time PCR

\section{Acknowledgements}

We would like to thank Chongqing 2D materials institute for providing technical support for Patch-clamp electrophysiology analysis.

\section{Authors' contributions}

WH, QD participated in the execution of the trial. $L J$ carried out Patch-clamp electrophysiology analysis. WH and JZ performed statistical analysis. WH drafted the manuscript. XJS initiated the project and provided the suggestion for editing and revising the manuscript. All authors read and approved the final manuscript.

\section{Funding}

This work was supported by the National Natural Science Foundation of China (No. 31660599 and 41661052). The funders had no role in study design, data collection and analysis, decision to publish, or preparation of the manuscript.

\section{Availability of data and materials}

The datasets used and/or analysed during the current study available from the corresponding author on reasonable request.

\section{Ethics approval and consent to participate}

Not applicable.

\section{Consent for publication}

Not applicable.

\section{Competing interests}

The authors declare that they have no competing interests.

\begin{abstract}
Author details
${ }^{1}$ College of Resources and Environment, Southwest University, Chongqing 400716, China. ${ }^{2}$ Vegetable and Flower Institute of Chongqing Academy of Agricultural Sciences, Chongqing 401329, China. ${ }^{3}$ Nanchang Institute of Technology, Nanchang 330099, China. ${ }^{4}$ Soil and Fertilizer \& Resources and Environment Institute, Jiangxi Academy of Agricultural Sciences, Nanchang 330200, China
\end{abstract}

Received: 28 October 2019 Accepted: 3 June 2020

Published online: 22 June 2020

\section{References}

1. Fageria NK, Barbosa MP, da Costa JGC. Potassium-use efficiency in common bean genotypes. J Plant Nutr. 2001;24(12):1937-45.

2. Miyamoto K, Takahashi A, Ueda J. Stimulation of hypocotyl elongation in etiolated lettuce seedlings by sodium chloride and potassium chloride at low concentrations: relevance to osmoregulation and cell wall mechanical properties. Plant Cell Physiol. 2003;44:S37.

3. Schwamberger EC, Sims JL. Effects of soil-Ph, nitrogen-source, phosphorus, and molybdenum on early growth and mineral-nutrition of burley tobacco. Commun Soil Sci Plan. 1991;22(7-8):641-57.

4. Chen JW. Integrated management of tobacco soil and nutrients in China, vol. 2. Beijing: Science Press; 2014.

5. Gaymard F, Pilot G, Lacombe B, Bouchez D, Bruneau D, Boucherez J, et al. Identification and disruption of a plant shaker-like outward channel involved in K+ release into the xylem sap. Cell. 1998;94(5):647-55.
6. Cherel I, Michard E, Platet N, Mouline K, Alcon C, Sentenac H, et al. Physical and functional interaction of the Arabidopsis K+ channel AKT2 and phosphatase AtPP2CA. Plant Cell. 2002;14(5):1133-46.

7. Wang $Y$, Wu WH. Potassium transport and signaling in higher plants. Annu Rev Plant Biol. 2013;64:451-76.

8. ten Hoopen F, Cuin TA, Pedas P, Hegelund JN, Shabala S, Schjoerring JK et al. Competition between uptake of ammonium and potassium in barley and Arabidopsis roots: molecular mechanisms and physiological consequences. J Exp Bot. 2010;61(9):2303-15.

9. Jung JY, Shin R, Schachtman DP. Ethylene mediates response and tolerance to potassium deprivation in Arabidopsis. Plant Cell. 2009;21(2):607-21.

10. Cao YW, Glass ADM, Crawford NM. Ammonium inhibition of Arabidopsis root-growth can be reversed by potassium and by auxin resistance mutations Aux1, Axr1, and Axr2. Plant Physiol. 1993;102(3):983-9.

11. Nawaz MA, Imtiaz M, Kong QS, Cheng F, Ahmed W, Huang Y, et al. Grafting: a technique to modify ion accumulation in horticultural crops. Front Plant Sci. 2016;7:1457.

12. Zhong YQ, Shi JD, Zheng ZH, Nawaz MA, Chen C, Cheng F, et al. NMR-based fruit metabonomic analysis of watermelon grafted onto different rootstocks under two potassium levels. Sci Hortic-Amsterdam. 2019;258:108793.

13. Zhong YQ, Chen C, Nawaz MA, Jiao YY, Zheng ZH, Shi XF, et al. Using rootstock to increase watermelon fruit yield and quality at low potassium supply: a comprehensive analysis from agronomic, physiological and transcriptional perspective. Sci Hortic-Amsterdam. 2018;241:144-51.

14. Nawaz MA, Chen C, Shireen F, Zheng ZH, Jiao YY, Sohail H, et al. Improving vanadium stress tolerance of watermelon by grafting onto bottle gourd and pumpkin rootstock. Plant Growth Regul. 2018;85(1):41-56.

15. Nawaz MA, Shireen F, Huang Y, Bie ZL, Ahmed W, Saleem BA. Perspectives of vegetable grafting in Pakistan: current status, challenges and opportunities. Int J Agric Biol. 2017;19(5):1165-74.

16. Dong HH, Niu YH, Li WJ, Zhang DM. Effects of cotton rootstock on endogenous cytokinins and abscisic acid in xylem sap and leaves in relation to leaf senescence. J Exp Bot. 2008;59(6):1295-304.

17. Ahmedi W, Nawaz MA, lqbal MA, Khan MM. Effect of different rootstocks on plant nutrient status and yield in Kinnow mandarin (Citrus reticulata Blanco). Pak J Bot. 2007;39(5):1779-86.

18. Nawaz MA, Han XJ, Chen C, Zheng ZH, Shireen F, Bie ZL, et al. Nitrogen use efficiency of watermelon grafted onto 10 wild watermelon rootstocks under low nitrogen conditions. Agronomy-Basel. 2018;8:11.

19. Hu W, Di Q, Wang ZJ, Zhang YM, Zhang J, Liu J, et al. Grafting alleviates potassium stress and improves growth in tobacco. BMC Plant Biol. 2019;19:130.

20. Huang Y, Li J, Hua B, Liu ZX, Fan ML, Bie ZL. Grafting onto different rootstocks as a means to improve watermelon tolerance to low potassium stress. Sci Hortic-Amsterdam. 2013;149:80-5.

21. Zhou YH, Zhou J, Huang LF, Ding XT, Shi K, Yu JQ. Grafting of Cucumis sativus onto Cucurbita ficifolia leads to improved plant growth, increased light utilization and reduced accumulation of reactive oxygen species in chilled plants. J Plant Res. 2009;122(5):529-40.

22. Nawaz MA, Wang LM, Jiao YY, Chen C, Zhao L, Mei MJ, et al. Pumpkin rootstock improves nitrogen use efficiency of watermelon scion by enhancing nutrient uptake, cytokinin content, and expression of nitrate reductase genes. Plant Growth Regul. 2017;82(2):233-46.

23. Huang $Y$, Jiao YY, Nawaz MA, Chen C, Liu L, Lu Z, et al. Improving magnesium uptake, photosynthesis and antioxidant enzyme activities of watermelon by grafting onto pumpkin rootstock under low magnesium. Plant Soil. 2016;409(1-2):229-46.

24. Yasinok AE, Sahin Fl, Eyidogan F, Kuru M, Haberal M. Grafting tomato plant on tobacco plant and its effect on tomato plant yield and nicotine content. J Sci Food Agric. 2009;89(7):1122-8.

25. Liu JJ, Li JQ, Su XH, Xia ZL. Grafting improves drought tolerance by regulating antioxidant enzyme activities and stress-responsive gene expression in tobacco. Environ Exp Bot. 2014;107:173-9.

26. Dabuxilatu I. M: distribution of $\mathrm{K}, \mathrm{Na}$ and $\mathrm{Cl}$ in root and leaf cells of soybean and cucumber plants grown under salinity conditions. Soil Sci Plant Nutr. 2005;51(7):1053-7.

27. Pilot G, Gaymard F, Mouline K, Cherel I, Sentenac H. Regulated expression of Arabidopsis shaker $\mathrm{K}+$ channel genes involved in $\mathrm{K}+$ uptake and distribution in the plant. Plant Mol Biol. 2003;51(5):773-87.

28. Riedelsberger J, Sharma T, Gonzalez W, Gajdanowicz P, Morales-Navarro SE, Garcia-Mata C, et al. Distributed structures underlie gating differences between the K-in channel KAT1 and the K-out channel SKOR. Mol Plant. 2010;3(1):236-45. 
29. Zhao FG, Song $\mathrm{CP}$, He JQ, Zhu H. Polyamines improve $\mathrm{K}+/ \mathrm{Na}$ + homeostasis in barley seedlings by regulating root ion channel activities. Plant Physiol. 2007;145(3):1061-72.

30. Sano T, Becker D, Ivashikina N, Wegner LH, Zimmermann U, Roelfsema MRG, et al. Plant cells must pass a K+ threshold to re-enter the cell cycle. Plant J. 2007:50(3):401-13.

31. Marschner H, Kirkby EA, Cakmak I. Effect of mineral nutritional status on shoot-root partitioning of photoassimilates and cycling of mineral nutrients. J Exp Bot. 1996;47:1255-63.

32. Very AA, Sentenac H. Molecular mechanisms and regulation of K+ transport in higher plants. Annu Rev Plant Biol. 2003;54:575-603.

33. Nieves-Cordones M, Martinez-Cordero MA, Martinez V, Rubio F. An NH4+sensitive component dominates high-affinity $\mathrm{K}+$ uptake in tomato plants. Plant Sci. 2007;172(2):273-80.

34. Maathuis FJM, Sanders D. Mechanism of high-affinity potassium uptake in roots of Arabidopsis-Thaliana. P Natl Acad Sci USA. 1994;91(20):9272-6.

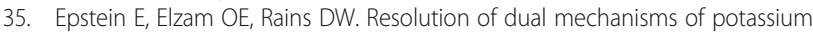
absorption by barley roots. P Natl Acad Sci USA. 1963;49(5):684.

36. Lei B, Huang Y, Sun JY, Xie JJ, Niu ML, Liu ZX, et al. Scanning ion-selective electrode technique and $\mathrm{X}$-ray microanalysis provide direct evidence of contrasting $\mathrm{Na}+$ transport ability from root to shoot in salt-sensitive cucumber and salt-tolerant pumpkin under $\mathrm{NaCl}$ stress. Physiol Plant. 2014; 152(4):738-48

37. Fu HH, Luan S. AtKUP1: a dual-affinity $\mathrm{K}+$ transporter from Arabidopsis. Plant Cell. 1998;10(1):63-73.

38. Wang TB, Gassmann W, Rubio F, Schroeder Jl, Glass ADM. Rapid upregulation of HKT1, a high-affinity potassium transporter gene, in roots of barley and wheat following withdrawal of potassium. Plant Physiol. 1998; 118(2):651-9.

39. Nass R, Cunningham KW, Rao R. Intracellular sequestration of sodium by a novel $\mathrm{Na}+/ \mathrm{H}+$ exchanger in yeast is enhanced by mutations in the plasma membrane H+-ATPase - insights into mechanisms of sodium tolerance. J Biol Chem. 1997;272(42):26145-52.

40. Deeken R, Geiger D, Fromm J, Koroleva O, Ache P, Langenfeld-Heyser R, et al. Loss of the AKT2/3 potassium channel affects sugar loading into the phloem of Arabidopsis. Planta. 2002;216(2):334-44.

41. Buschmann PH, Vaidyanathan R, Gassmann W, Schroeder Jl. Enhancement of Na+ uptake currents, time-dependent inward-rectifying $\mathrm{K}+$ channel currents, and $\mathrm{K}+$ channel transcripts by $\mathrm{K}+$ starvation in wheat root cells. Plant Physiol. 2000;122(4):1387-97.

42. Maathuis FJM, Filatov V, Herzyk P, Krijger GC, Axelsen KB, Chen SX, et al. Transcriptome analysis of root transporters reveals participation of multiple gene families in the response to cation stress. Plant J. 2003;35(6):675-92.

43. Zhu XY, Chen YG, Chen H, Li X, Peng YZ, Wang SY. Minimizing nitrous oxide in biological nutrient removal from municipal wastewater by controlling copper ion concentrations. Appl Microbiol Biotechnol. 2013;97(3):1325-34.

44. Kochian LV, Shaff JE, Kuhtreiber WM, Jaffe LF, Lucas WJ. Use of an extracellular, ion-selective, vibrating microelectrode system for the quantification of $\mathrm{K}+, \mathrm{H}+$, and $\mathrm{Ca} 2+$ fluxes in maize roots and maize suspension cells. Planta. 1992:188(4):601-10.

45. Xu Y, Sun T, Yin LP. Application of non-invasive microsensing system to simultaneously measure both $\mathrm{H}(+)$ and $\mathrm{O}(2)$ fluxes around the pollen tube. J Integr Plant Biol. 2006;48(7):823-31.

46. He JL, Li H, Ma CF, Zhang YL, Polle A, Rennenberg H, et al. Overexpression of bacterial gamma-glutamylcysteine synthetase mediates changes in cadmium influx, allocation and detoxification in poplar. New Phytol. 2015; 205(1):240-54

47. Sun J, Chen SL, Dai SX, Wang RG, Li NY, Shen X, et al. NaCl-induced alternations of cellular and tissue ion fluxes in roots of salt-resistant and saltsensitive poplar species. Plant Physiol. 2009;149(2):1141-53.

48. Luo J, Qin JJ, He FF, Li H, Liu TX, Polle A, et al. Net fluxes of ammonium and nitrate in association with $\mathrm{H}+$ fluxes in fine roots of Populus popularis. Planta. 2013;237(4):919-31.

49. Livak KJ, Schmittgen TD. Analysis of relative gene expression data using real-time quantitative PCR and the 2 (T) (-Delta Delta C) method. Methods. 2001;25(4):402-8.

\section{Publisher's Note}

Springer Nature remains neutral with regard to jurisdictional claims in published maps and institutional affiliations.

Ready to submit your research? Choose BMC and benefit from:

- fast, convenient online submission

- thorough peer review by experienced researchers in your field

- rapid publication on acceptance

- support for research data, including large and complex data types

- gold Open Access which fosters wider collaboration and increased citations

- maximum visibility for your research: over $100 \mathrm{M}$ website views per year

At BMC, research is always in progress.

Learn more biomedcentral.com/submissions 